\title{
Promotion of Lifelong Education for Children in the Digital Era
}

\author{
Waiwoot Boonloy \\ Faculty of Education \\ Srinakharinwirot University \\ Thailand \\ waiwoot@hootmail.com
}

\begin{abstract}
Promoting lifelong education for preschool children in the digital era is very important because children are important human resources for future development in every country. The United Nations Educational, Scientific and Cultural Organization (UNESCO) has organized and managed the education system to help countries. It has the quality of lifelong learning with everyone, and most importantly, technical support is provided in a formulation and policy guideline. In response to the challenges and expected of work life. UNESCO has developed and supported strong programs at all levels of education. Early Childhood Care and Education (ECCE) provide care and development for children from birth to 8 years, which is a priority in the workplace of the organization. UNESCO has worked with governments and associates. Expand the benefits and quality of care and development with children from birth to 8 years in the world and focus childhood for a long time.
\end{abstract}

Keywords-Digital era; laws; lifelong education; policies; Thailand

\section{INTRODUCTION}

World population in the year 2560 is estimated. $7,574,718,500$ people are newly born children, about 111,698,000 people (worldometers, 2017, online). The population of Thailand in 2017 is 65,931,550 people. Register Children aged 8 years and older were 6,652,322 people, accounting for 10.1 percent of the total population $3,420,639$ boys and 3,231,683 girls.

Promoting lifelong education for preschool children in the digital era is very important because children are important human resources for future development in every country. The United Nations Educational, Scientific and Cultural Organization (UNESCO) has organized and managed the education system to help countries. It has the quality of lifelong learning with everyone, and most importantly, technical support is provided in a formulation and policy guideline. In response to the challenges and expected of work life. UNESCO has developed and supported strong programs at all levels of education. Early Childhood Care and Education (ECCE) provide care and development for children from birth to 8 years, which is a priority in the workplace of the organization. UNESCO has worked with governments and associates. To expand the benefits and quality of care and development with children from birth to 8 years in the world and focus childhood for a long time (unesco. 2016, online).

Causes of Child Problem Conditions with the Internet Revolutionary technology revolution in Thai society/ Thai children do not handle and have many problems as Technological revolution: speedily and embracing the country with globalization. Gap between society Technology inequalities: digital divide[1]. Family Status: Single Family Split and cut off the countryside. Generation Change: Population Proportion Environment and worldview. Education: lack of promotion of media literacy and information technology. Social Values: Focus on Convenience Buy/ use/ have/ procure technology. Government policy: lack of protection, promotion, support and protection of children. Care agency: lack of law protecting children and youth from online media. And Role of media: create - send - add Using technology and not knowing how to know.

According to the data of the world population and the number of children in Thailand, It is the information to promote and support the development of children and youth in accordance with the guidelines of UNESCO and to find solutions to the current problems of children and youth in Thailand.

\section{RESULT AND DISCUSSION}

\section{A. Lifelong Education}

The following present's paper involving Lifelong educations are formal non-formal and informal education. First the definitions and concepts of both are offered. Then problems concerning formal non-formal and informal education are discussed.

Non-formal education is a flexible study to determine the purpose, style, method of education management. Duration Measurement and evaluation, this is a critical condition of graduation. Curriculum and content are appropriate and appropriate to the problems and needs of learners of all age groups to access all types of learning centers. Informal education is a form of educational management that allows learners to self-learn according to their interest's potential readiness and opportunity by studying people experiences environments media or other learning networks[2]. 
The problem in the non-formal and informal education can be divided in these areas. First, equality of access which has been studied thoroughly (Chitradap; Charoenyakul and others. 2013: pp.3-4). Second, Decentralization to educational institutions in non-formal education and informal education was found that the budgeting and budgeting of each activity was in line with the plan. The budget was not enough for the activities and the power to disburse the money at the provincial office, thus delaying the allocation of budget to the district and sub-district administrative units.

\section{B. Law And Policy of Lifelong Education Since Childhood}

Law and policy on promotion of lifelong education since childhood are stated in the Constitution of the Kingdom of Thailand B.E. 2560. The National Education Act, B.E. 2542 Non-formal and informal education Act, B.E. 255describe the lifelong learning that commence from childhood period. The compulsory education Act, B.E. 2545, the Child Protection Act, B.E. 2546. In addition, the National Child and Youth Development Act, B.E. 2550 and the National Child and Youth Development Act (No. 2), B.E. 2560, National education plan 11-12 the development describe the plan for the digital economy and society of the digital economy and policy of government for 6 years ago.

2.1 Constitution of the Kingdom of Thailand B.E. 2560 in article 54 gives right and freedom in education and focus at equality of access which has been studied thoroughly and promotion lifelong education for people and the right to education to receive free education not less than twelve years from the state. [4].

2.2 The National Education Act, B.E.2542 has concept to management lifelong education for people and 3 models are formal education non-formal education and informal education. To participation of every part to educate, to bring technology for education and people can study or search knowledge by themselves[3].

2.3 Non-formal and informal education Act, B.E. 2551 has 25 articles that it is direct law to non-formal and informal education and important details are promotion lifelong education for people[4] .1) to manage course or activity education for every target group.in the non-formal education. 2) to choose program or activity which interesting from Learning Center. 3) To promotion non-formal and informal education by participation many organization from government company local government and community etc. 4) to decentralized by board of non-formal and informal education in province and deictic to administrative about education and 5) having an educational quality assurance system which the standard set by the law.

2.4 The compulsory education Act, B.E. 2545 has According to the Compulsory Education Act, B.E. 2545, for the purposes of this Act, The National Education Act requires that parents or guardians have the obligation to provide a nineyear compulsory education for children or persons in custody. The seventh grader is enrolled in elementary school until the age of sixteen, Except for the ninth year of compulsory education. It is recommended to amend the law on primary education. To be appropriate and consistent with the law, it is therefore necessary to enact this Act[5].
The substance in Article 4 of this Act "Compulsory education" means the first year of education to the nineteenth year of the basic education under the law on national education; "educational institution" means a school which provides compulsory education; "guardian" means a parent or parent who is a parent or guardian of the Civil and Commercial Code. "Child" means a child whose age is seven years old until the age of the child entering the sixteenth year, Except for children who have passed the ninth grade of compulsory education.

Article 5 Local administrative organizations, as the case may be, to publish details of the sending of children to educational institutions. The educational opportunities offered by educational institutions are subject to compulsory education. The local government organization and educational institution must also provide written notice to the child's guardian prior to attending school for not less than one year.

Article 6 Parents shall send their children to the school when the parents request. Educational institutions shall have the power to grant admission to children before or after their compulsory education according to the criteria and methods prescribed by the Basic Education Commission.

In summary, the essence of this law is intentional. Parents are responsible for compulsory education and participation in education by local governments and parents together.

2.5 The Child Protection Act, B.E. 2546 [7]. The reason for this Act is essentials and details on how to support Welfare protection and promote the conduct of children. Not suitable for current social conditions. It is important to set the stage and improve the way you treat your children, to provide the child with foster care and appropriate development. It promotes the stability of family institutions. The child is abused. As a tool to exploit wrong, or being discriminated against, it should also improve the cooperation between the public and private sectors in promoting child protection. To comply with the Constitution of the Kingdom of Thailand, National Economic and Social Development Plan and the Convention on the Rights of the Child, It is necessary to enact this ordinance.

This Act has a total of 88 articles, and the key under Article 4 "Child" means a person who is under the age of 18 but excludes to those who are underage by marriage.

Article 26 Subject to the provisions of other laws, whether the child will agree or not No one do the following: (1) commits or abstains from physical abuse; or the mind of the child (2) deliberate or neglectful of necessity for life or healing; The nurses of the children in their care until the danger, The body or mind of the child. (3) Forcing, threatening, encouraging or permitting children to behave. It is important to make sure that your child is behaving appropriately. (4) To advertise by mass media or disseminate to children. Or raising children to other people who are not relatives of children, unless Act of government or approved by the government. (5) To force, threaten, induce, promote, and consent or to act in any way; let the children go begging. Children are used as tools. Begging or offending or do any of that abuse of children, (6) Employ or hire children to work or commit dangerous activities. The body or mind affects growth or obstruction. (7) To force, threaten, induce, encourage or permit the child to play sports or any action to seek 
commercial advantage. Is like Interfering with the growth or development of children or Cruelty to children (8) Use or permit children to gamble of any kind or to enter, Gambling prostitution or place forbidden children. (9) Forcing, threatening, inducing or encouraging the child to show or Acting on pornographic material, whether it is to gain Compensation or for any purpose.

Article 27 Advertising and dissemination of information about children intentionally Damage to the mind, reputation or honor, or to seek Benefit for yourself, or wrong people

Child welfare

Article 32 Children to be reimbursed are children who have been wrongly raised. It is used as a tool to act or exploit wrongly. Be abused or fallen into any other condition which may cause the child to have behave morally well or cause harm to Physical or mental, including orphans, orphans, abandoned children and children in difficult conditions.

Child Protection

Article 40 Children who are protected by the law include abused children. Children at risk and the children in the condition that must be protection as prescribed in the Ministerial Regulations;

Article 41 Persons who encounter abusive behavior against children shall immediately notify their employees administrative Officer or the police immediately and to the staff. The authorities have the power to separate children from their families as soon as possible.

Article 42 Protection of child welfare must provide physical therapy and immediately if the officer sees fit, May be taken to the first place, First, during the inquiry and observation to find a way to protect the welfare and appropriate image.

In summary, having the Child Protection Act, B.E.2546is an important law. To support the protection of children under the age of is in the treatment of children as provided by law, protected and abusive behavior towards children.

2.6 The National Child and Youth Development Act (No. 2), B.E. 2560. The reason for the promulgation of this Act is that the Child Development Act. There are some provisions that are inappropriate for the current situation. Promote children and youth at all levels to participate in the development of children and youth. Effective Including encouraging children and youth to participate in the forum, the impact on children and youth, it also encourages children and youth to express them in accordance with the level knowledge that develops along the age of children and youth. Amendments should be made to the promotion. Youth development is more effective. It is therefore necessary to enact this Act[6]. This Act has a total of 38 articles, and the key under article 3 defines the term "Executive Board" means the Executive Board of the Tambon Children and Youth Council, Executive Committee of the Municipality Youth Council, Executive Committee of the District Youth Council, Executive Committee of Provincial Youth Council, Executive Committee of Bangkok Youth and Children Council And the Board of Directors of the Children and Youth Council of Thailand.

Article 4 Action under paragraph one to do this, follow these steps: (1) Provide children and youth with family ties. We are proud of being Thai. There is a democratic way of life.(2) To live safely know respect for the rights and freedoms of others, Including laws, rules and regulations in society.(3) To support and promote educational cooperation, both domestic and foreign. All children and youth have access to education.(4) To support and promote education for disabled children, Children with learning limitations and children with special abilities, to be self-reliant, to have virtue and good quality of life, to be able to pursue a career and live independently.(5) To have a healthy and well-being. Know how to protect yourself from diseases and addictions.(6) Have reasonable emotional maturity for the ages, The moral and ethical.(7) To have good skills and attitudes towards work. Dignity and pride in working in good faith (8). Let's think logically and continuously develop self.(9) To help others with the consciousness of giving and volunteering. It also contributes to the development of the community and the nation (10). To be responsible for themselves and others. Suitable for ages to be able to express opinions or expressions in accordance with the knowledge and ability developed by the children and youth (11). Especially those that affect children and youth and(12) To be able to participate in the judicial process in matters affecting children and youth appropriately, Whether directly or through representatives or organizations for children and youth.

Article 6 requires the representatives of the local administrative organization to come to the committee of 3 persons by choosing each other.

Article 22 to have The Children and Youth Council by The municipal administrative organization, with the advice of the head nursing home and family in each province. The District Council for Children and Youth, as the case may be members include children and young people in the Tambon administrative organization area.

Article 23 Determination of the powers and duties of the Council for Children and Youth, (1) Youth Council District Youth Council to exchange knowledge and experience in various aspects of children and youth.(2) Promote and support the learning, academic, educational, health, sport, occupational and local culture of children and youth.(3) Encourage children and young people to express their views or express themselves in accordance with the knowledge and skills developed by their children or youth, especially those that affect children and youth.(4) Organize activities to promote and develop local children and youth, Including morals and ethics.(5) To gather information, suggestions or assess the impact on children and youth in the area to forward such information to the District Youth Council.(6) To provide opinions to the agencies concerned with the promotion and development of children and youth as well as to solve problems affecting children and youth in the area.(7) To recommend and give opinions to the District Youth Council, about the promotion and development of children and youth in the local.(8) Propose opinions to the board on the performance of government agencies and NGOs or community organizations related to children and youth in the area and (9) To issue regulations on meetings and performance of duties and responsibilities by the Executive Board of the Youth Council or the Executive Committee of the Council of Youth, as the case may be to comply with the regulations of the Council of Children and Youth of Thailand. 
Article 24 Members of the District Youth Council District in the province And in Bangkok. The District Youth and Children Council the members include the youth council of the district council and the municipal youth council in the district area, the district children and youth in Bangkok the members are children and young people in each Bangkok area.

Article 25 Powers and Duties of District Youth Council Members District in the province and in Bangkok, The District Youth Council and the Children's Council District. Authority as follows(1) Coordinate between the District Youth Council for Children and Youth Provincial and the Bangkok Children and Youth Council to exchange knowledge and experience in various aspects of children and youth.(2) Promote and support the academic, academic, educational, health, sports, the local youth culture and occupation(3) Encourage children and youth to express their views or express their views in a consistent manner, with the ability to develop by the age of children or youth, especially those that affect children and Youth. (4) Organize activities to promote and develop local children and youth, including morals and ethics.

Article 30 The Children and Youth Council of Thailand, There are consultants from various ministries. The Children and Youth Council of Thailand the members consist of: (1) Chairman of the Provincial Children and Youth Council from all provinces.(2) President, Bangkok Children and Youth Council; (3) Children and Youth Representative They come from a selection of children and youth who have registered in accordance with the regulation of the Minister. The diversity of children and youth, including the disabled and the underprivileged Thirty-eight

Article 31 Authority and Functions of the Children and Youth Council of Thailand.

Section 36 The Department of Children and Youth Affairs shall be encouraged and supported.

Article 37 and 38 the Conference and the Scheduling of Meetings.

In summary, having The National Child and Youth Development Act (No. 2), B.E. 2560is an important law, to support the promotion children and youth to participate in the development of children and youth. It is a law that came out. Local administrations are set up at sub-district, district and provincial levels Bangkok and at the central level, Determining authority and composition of district youth council members, District in the province and in Bangkok and the Council of Children and Youth of Thailand and the Department of Children and Youth Affairs to encourage and support.

2.7 National education plan 12 (B.E.2560-2564) has the key principles as the center people of development under that vision to develop the learners with knowledge of the moral. Have a good quality of life Happy in society. The national education plan has been defined as a continuing education for life. The strategies are as follows: 1) Expand access to education and lifelong learning services. The aim is to provide educational services to learners of all age groups at a level appropriate to the context and condition of the area. 2) Promote and develop digital technology for education. The aim is to provide Thai people with lifelong learning opportunities through the use of information technology, which responds to developments in access to services.
Equality and efficiency and 3) develop a management system and encourage all sectors to participate in educational management. It is well worth the budget and personnel resources. No waste and mobility for Thai people to have a lifetime of quality. Develop people around the balance and balance as the basis of development (Ministry of Education, 2017).

2.8 The Digital Economy and Social Development Plan of the Ministry of Digital for Economic and Social (Ministry of Digital Economic and Social, 2017)

According to the third strategy, creating a society of equal quality through digital technology will create Thailand for all people, especially farmers. Those in remote communities, the elderly, the underprivileged and the disabled can access and utilize services. The state through digital technology has national and local knowledge information in a digital format that people can access and use easily. And people who know information. And have the skills to take advantage of digital technology with social responsibility. This strategy consists of a roadmap for five strategies. 1) Create opportunities and equality in accessing and utilizing digital technology for the people in particular. Elderly people with disabilities Group of people living in remote areas 2) Improve people's ability to use digital technology for their benefit and creativity, as well as their ability to think. And distinguish information in digital society that is open and free. 3) Create media, media and digital learning resources for lifelong learning accessible to the public. Throughout the telecommunication system, Broadcasting system and fusing media. 4) Increase the opportunity to receive standardized education of students and people of all ages, anywhere, anytime, with digital technology and 5) Increase the opportunities for modern medical and health services that are up to date and equal to the high society with digital technology.

2.9 Policy of Thailand government for 6 years ago.

Government Policies, The past education policy has focused on educational reform. Participation in education for the private sector, Local governments and people take part in the management. Education development having educational opportunities from getting free education. To create educational opportunities, spread educational opportunities, taking into account the creation. Equality and fairness for all populations, teacher development, and educational personnel. To get good teachers, virtue, quality and higher academic credentials. The quality of life of teachers has been maintained through debt restructuring and the establishment of the Teacher Quality Development Fund Along with the investment in information technology, the development of content and personnel to fully support and utilize the information technology system, etc. The quality of higher education standards in vocational and higher education. To create skilled workers to meet labor demand. As well as improving the management system of educational loan funds. To give people access to the cost of education. Promote integrated learning. To foster a continuous learning society throughout life in the community and the use of information technology for education.

On October 16, 2560, there was a meeting at the level of the committee for consultation on the integration of early childhood information. By the Deputy Prime Minister chairs 
the meeting along with the Executive Secretary of the Education Council, Representatives from relevant agencies to integrate information and information systems of preschool children. The link between the four main agencies: Ministry of Public Health Ministry of the Interior Ministry of Social Development and Security and the Ministry of Education including other agencies.

The essence is as follows. Information and Information System Integration of Early Childhood, It is the cooperation between the four major agencies: Ministry of Public Health, Ministry of the Interior, Ministry of Social Development and Human Security and the Ministry of Education including other agencies. The first phase of the study was to survey the data of each unit thoroughly and accurately. To complete by November, Especially, The Prime Minister has instructed the National Information System (Big Data) to integrate early childhood information into one of the information systems to be provided. Linking to public services 2) Linking to public administration to enhance efficiency and 3) Linking to security, in particular, the use of information for public service to the public(Office of the Education Council, 2017)

\section{Adjustment of laws and policies related to the promotion of lifelong education to keep pace with the changes in the Thailand}

Adjustment of the law and policy of non-governmental organizations related to lifelong education to keep up with changes in the digital age. It is very important. It is suitable for service needs of people with diverse target groups. It is very necessary. Especially it is a channel for people outside the school system to be a diverse group of people and socially disadvantaged. The need to access educational information in various forms the principles of promoting non-formal education and informal education. Low cost Modern Use with a lot of people. Convenient and easy access to a variety of channels and a variety of formats. Sharing resources between agencies, the use of knowledgeable people to manage digital technology. The software has helped to access educational information and to make the application in interesting ways to access the information. For many people and a wide range of target groups who are equipped with the latest information technology equipment.

On bringing digital technology was used to create a modern society and access to quality education is more convenient and protect children; 1) Integrating the legal aspects related to child protection, To easily access content and implement it with the help of technology.2) The use of media in various forms in public relations. To protect children and youth both in the track protection feature. Protection and remission3) Establishing a database of children and youth in an integrated manner from several related units. To get accurate and up-todate information and 4) providing insights related to child protection. To the public, there are many forms of disasters affecting children and youth.

\section{CONCLUSION}

Laws and guidelines related to the promotion of formal nonformal and informal education. It has to be up-to-date and adapt the laws and guidelines to keep pace with the changes of the Thai-language, or to adjust the laws and guidelines for more proactive advances to be a mechanism and a tool to drive economic, social, political and educational development and work in an integrated manner between the public and private sectors in formal non-formal and informal education. This is leading to a system of education and low-cost work. In the next 5-10 years, there are alternative ways to educate people outside the school system. Lifelong Learning Systems, a guide to promoting and supporting lifelong education in the future for children and youth and all people.

\section{References}

[1] T. Chuastapanasiri, "Causes of Child Problem Conditions with the Internet, "Digital Media for Children and Thai Youth," SubCommittee Promot. Prot. Child. Young People from use online media, 2016.

[2] Royal Academy, Dictionary of education, Bangkok. Arun Printing, 2012.

[3] M. of E. Department of General Education, National Education Act B.E. 2542 and the analysis of the essence Bangkok. Bangkok: Kurusapa Printing Ladphrao, 1999.

[4] Ratchakitcha, "The Compulsory Education Act," B.E. 2545, vol. Vol. 119,

[5] "The Child Protection Act," B.E. 2546, vol. Vol. 120,

[6] C. D. Commission, "Constitution of the Kingdom of Thailand BE 2550 (2007)," Bangkok Bur. Print. Serv. Secr. House Represent., 2007. 